(C) 2015

\author{
Папка О. С., аспірант
}

(науковий керівник - доктор сільськогосподарських наук, професор П. В. Писаренко)

Полтавська державна аграрна академія

\title{
ДЕЯКІ ПИТАННЯ БІОЛОГІЇ ПРОРОСТАННЯ ВАТОЧНИКА СИРІЙСЬКОГО
}

\section{Рецензент - доктор сільськогосподарських наук, професор М. Я. Шевніков}

Представлено результати досліджень, які свідчать про те, щзо зародок сім'я ваточника сирійського через 1-1,5 місяия після збору изілком здатний до зростання, причому умови проростання для свіжозібраного насіння потрібно такі ж, як $і$ для дозрілого. $B$ умовах, щчо відхиляються від оптимальних, свіжозібране насіння проростає приблизно так само, як $і$ дозріле. Все иче вказує на те, щцо післяжнивне дозрівання у насіння ваточника є слабко вираженим.

Ключові слова: ваточник сирійський (Asclepias syriaca L. sys. A. Cornuti Decne.), медоноси, каучук, проростання.

Постановка проблеми. Ваточник (Asclepias syriaca L. sys. A. Cornuti Decne.) представляє інтерес 3 точки зору комплексного його використання: він $\epsilon$ медоносом; в його листі міститься смолянистий каучук; пушок може служити для виготовлення спеціальних тканин і прокладень, а насіння містить жирну олію. 3 ваточника сирійського намагались отримувати каучук, оскільки в його соку були виявлені компоненти каучуку i смоли. 3 цією метою його культивували у ботанічних садах Петербургу, а пізніше - в Київському ботанічному саду і у Білій Церкві. Але виробництво каучуку виявилося трудомістким і дорогим, до того ж каучук виходив низької якості. Йшов час, розвиток промислових технологій привів до появи високоякісного каучуку. I до ваточника, як до сировини, втратили інтерес. Вирощувався він і як декоративна рослина. Після неодноразових спроб промислового вирощування цей вид вільно поширився серед природних рослинних груп [3].

Аналіз останніх досліджень і публікацій, у яких започатковано розв'язання проблеми. У літературі про насіння ваточника можна зустріти лише мізерні дані. Поплавський [2] відмічає необхідність високих температур для проростання насіння ваточника. Кузьменко [1] повідомляе, що позитивна дія на проростання робить попереднє замочування насіння ваточника при температурі $30{ }^{\circ} \mathrm{C}$ протягом 12 годин.

Мета досліджень - визначити роль різних екологічних чинників у проростанні насіння ва- точника (Asclepias syriaca L. sys. A. Cornuti Decne).

Результати досліджень. Проведені нами досліди при різних температурах, у тому числі і змінних, виявили вирішальну роль температурного чинника в проростанні насіння ваточника. Ці досліди показали, що найкращі результати виходять при змінній температурі, по можливості з широкою амплітудою коливань. Температури $10-30{ }^{\circ} \mathrm{C}$ i $5-30{ }^{\circ} \mathrm{C}$ дають однакові результати. Під час зміни температур необхідно, щоб висока температура мала більший період протягом добових коливань. Температури $20{ }^{\circ} \mathrm{C}$ і навіть $25^{\circ} \mathrm{C}$ дають дуже низьку схожість, тоді як при $30{ }^{\circ} \mathrm{C}$ схожість дорівнює приблизно двом третинам за оптимальних умов. При $10{ }^{\circ} \mathrm{C}$ проростання не було відмічено впродовж тривалого терміну.

Таким чином, неодмінною умовою проростання насіння ваточника $\epsilon$ в першу чергу досить висока температура. Застосовуючи різку зміну температур, можна значно підвищити схожість. Приведемо середні показники енергії проростання і схожості при різних температурах по 14-ти зразкам насіння. Випробування здійснювалися через 7-8 місяців після збору насіння (табл. 1). Результати досвіду зі свіжозібраним насінням (через $1-1,5$ місяців після збору) наводяться в таблиці 2.

Дані досвіду свідчать про те, що свіжозібране насіння у вимогах до умов проростання по суті не відрізняється від давньозібраних. На енергію проростання і схожість насіння ваточника помітно впливає стратифікація. У наших дослідах насіння заздалегідь намочувалося, потім змішувалося 3 вологим піском i близько місяця витримувалося при температурі $0^{\circ} \mathrm{C},+5^{\circ} \mathrm{C},+10^{\circ} \mathrm{C}$ (табл. 3).

У оптимальних умовах проростання $\left(10-30{ }^{\circ} \mathrm{C}\right.$ 3 різкою зміною температур) стратифіковане насіння настільки дружно проростає, що енергія проростання дорівнює кінцевій схожості. Схожість стратифікованого насіння за усіх умов вища за схожість насіння непідготовленого. При $20{ }^{\circ} \mathrm{C}$, а тим більше при $10{ }^{\circ} \mathrm{C}$ схожість стратифікованого насіння нижча, ніж при $10-30{ }^{\circ} \mathrm{C}$, проте значно перевищує схожість контролю. 
СТОРІНКА МОЛОДОГО ВЧЕНОГО

1. Характер проростання насіння ваточника при різних температурах

\begin{tabular}{|c|c|c|c|c|c|c|}
\hline \multirow{2}{*}{ Показники } & \multicolumn{7}{|c|}{ Температура } \\
\cline { 2 - 7 } & $10{ }^{\circ} \mathrm{C}$ & $20{ }^{\circ} \mathrm{C}$ & $30{ }^{\circ} \mathrm{C}$ & $\begin{array}{c}20-30{ }^{\circ} \mathrm{C} \\
(6 \text { г) }\end{array}$ & $\begin{array}{c}10-30{ }^{\circ} \mathrm{C} \\
(6 \text { г) }\end{array}$ & $\begin{array}{c}10-30{ }^{\circ} \mathrm{C} \\
(18 \text { г) }\end{array}$ \\
\hline $\begin{array}{c}\text { Енергія } \\
\text { проростання }\end{array}$ & - & 12 & 41 & 31 & 5 & 47 \\
\hline Схожість & 1 & 15 & 48 & 59 & 61 & 75 \\
\hline
\end{tabular}

2. Проростання свіжозібранного насіння ваточника

\begin{tabular}{|c|c|c|c|c|c|c|c|}
\hline \multirow{2}{*}{ Показники } & \multicolumn{7}{|c|}{ Температура } \\
\cline { 2 - 8 } & $5^{\circ} \mathrm{C}$ & $10^{\circ} \mathrm{C}$ & $20{ }^{\circ} \mathrm{C}$ & $30{ }^{\circ} \mathrm{C}$ & $\begin{array}{c}20-30{ }^{\circ} \mathrm{C} \\
(6 \text { г) }\end{array}$ & $\begin{array}{c}10-30{ }^{\circ} \mathrm{C} \\
(6 \text { г) }\end{array}$ & $\begin{array}{c}10-30{ }^{\circ} \mathrm{C} \\
(18 \Gamma)\end{array}$ \\
\hline $\begin{array}{c}\text { Енергія } \\
\text { проростання }\end{array}$ & - & - & 15 & 50 & 25 & 1 & 35 \\
\hline Схожість & - & 1 & 18 & 70 & 40 & 35 & 78 \\
\hline
\end{tabular}

3. Проростання стратифікованого насіння ваточника (\%)

\begin{tabular}{|c|c|c|c|c|c|c|c|c|c|}
\hline \multirow{4}{*}{ Показники } & \multicolumn{9}{|c|}{ Умови підготовки насіння } \\
\hline & \multicolumn{3}{|c|}{$0^{\circ} \mathrm{C}$} & \multicolumn{3}{|c|}{$+5{ }^{\circ} \mathrm{C}$} & \multicolumn{3}{|c|}{$+10^{\circ} \mathrm{C}$} \\
\hline & \multicolumn{9}{|c|}{ Температура пророщування } \\
\hline & $\begin{array}{c}10-30^{\circ} \mathrm{C} \\
(18 \text { г) }\end{array}$ & $20{ }^{\circ} \mathrm{C}$ & $10^{\circ} \mathrm{C}$ & $\begin{array}{c}10-30{ }^{\circ} \mathrm{C} \\
(18 \text { г) } \\
\end{array}$ & $20^{\circ} \mathrm{C}$ & $10^{\circ} \mathrm{C}$ & $\begin{array}{c}10-30^{\circ} \mathrm{C} \\
(18 \text { г) }\end{array}$ & $20^{\circ} \mathrm{C}$ & $10^{\circ} \mathrm{C}$ \\
\hline $\begin{array}{c}\text { Енергія } \\
\text { проростання }\end{array}$ & 82 & 30 & 18 & 89 & 35 & 14 & 90 & 7 & 2 \\
\hline Схожість & 86 & 60 & 45 & 90 & 61 & 35 & 91 & 25 & 7 \\
\hline
\end{tabular}

Не можна не звернути уваги на той цікавий факт, що чим нижче температура стратифікації насіння, тим вище їх подальша схожість при $20{ }^{\circ} \mathrm{C}$ і $15^{\circ} \mathrm{C}$. Звідси випливає, що температурні умови підготовки (стратифікаціі) істотним чином впливають на зміщення температурного мінімуму проростання насіння ваточника.

Висновок. У наших дослідах насіння через $1-1,5$ місяця після збору проростало в оптимальних умовах майже повністю. Це свідчить про те, що зародок сім'я в цей час цілком здатний до

\section{БІБЛІОГРАФІЯ}

1. Кузьменко А. А. Про ластовень, його розповсюдження та культуру на Україні / А. А. Кузьменко // С.-г. ботаніка, 1929.

2. Поплавський К. М. К биологии проростання семян каучуконосов // Тр. Института плодовых зростання, водночас умови проростання для свіжозібраного насіння потрібно такі ж, як і для тих, що дозріли. Крім того і в умовах, що відхиляються від оптимальних, свіжозібране насіння проростає приблизно так само, як і те, що дозріло. Все це вказує на те, що післяжнивне дозрівання у насіння ваточника якщо і $€$, то, в усякому разі, виражено нечітко. Розтягнуте проростання і неповна схожість насіння, що вилежалося, та свіжозібраного, обумовлені одними і тими ж причинами.

культур, 1935.

3. Шувар I. Новій поселенець українських земель // Агробізнес сьогодні. - №3 (250). 2013. - C. 24-26. 